\title{
Energy Saving by the Means of Geothermal Energy
}

\author{
Abeer S. Abu Raed and Ahmad H. Sakhrieh
}

\begin{abstract}
The Earth houses a vast energy supply in the form of geothermal resources. This energy can be used in several applications. In this work the potential of energy saving using geothermal energy in residential sector in Jordan was investigated. The use of geothermal energy for both domestic hot water and in HVAC systems was studied. Two types of geothermal heat exchangers were presented in this work; cast iron heat exchanger for HVAC systems and polyethylene for domestic hot water. Energy consumption can by reduced up to $30 \%$ by installing geothermal heat exchanger
\end{abstract}

Index Terms-Energy, geothermal, Jordan.

\section{INTRODUCTION}

The temperature of the ground surface is a function of the climate and altitude. The temperature of the ground surface is approximately the same of the ambient temperature. Going inside the earth, the dependence on the ambient climate conditions is ${ }^{1}$ decreasing. Earth temperature a few meters below its surface maintains constant through the year. This warm earth provides a free renewable source of energy that can provide energy year around to heat and cool residential houses. Due to the stable temperature of the ground, the heating and cooling systems which are dependent on geothermal energy are more efficient than conventional heating and air-conditioning technologies. Geothermal energy is used also in electricity generation (geothermal power plants), and in industrial fields. It is sustainable, environmentally friendly and need no fuel to produce power.

With a rapidly growing world population, and ever-increasing environmental concerns, sustainable development has become an issue of crucial importance for mankind. Geothermal resources have the potential of contributing significantly to sustainable energy use in many parts of the world. Sustainable geothermal utilization involves energy production at a rate which may be maintained for a very long time (100-300 years). The production capacity of geothermal systems is quite variable and different systems respond differently to production, depending on their geological setting and nature. Therefore, comprehensive management is essential for the sustainable use of all geothermal resources. In other words, efficient management is required in order to avoid overexploitation, which mostly occurs due to lack of knowledge and poor understanding as well as in situations when many users utilize the same resource, without common management. Energy-efficient utilization, as well as careful monitoring and

Manuscript received December 21, 2012; revised February 7, 2013.

A. Abu Raed is with Architecture Engineering Department, Al-Zaytoonah Private University of Jordan, Amman, Jordan (email: arc_77a@yahoo.com).

A. Sakhrieh is with Mechanical Engineering Department, The University of Jordan, Amman, Jordan modeling, are essential ingredients in sustainable development. Reinjection is also essential for sustainable utilization of geothermal systems, which are virtually closed and with limited recharge [1].

The GHP or GSHP is considered to be one of the world's fastest growing renewable energy applications [2], [3]. They have an annual increase of about $10 \%$ in the USA and Europe. The reported number of installed units all over the world exceeds one million. The main advantage of the GHP is that it utilizes the ground temperature as a source of heat. Extensive research has been found in the literature on GSHP systems, particularly on the single U-tube ground heat exchanger [4]-[7] or in the general closed-loop GSHP [8]. Recently, some designs used horizontal closed loops for heating and cooling applications [9], [10].

GE has been produced commercially for over 80 years, and for four decades on the scale of hundreds of megawatts both for electricity generation and for direct use. The utilization of GE has increased rapidly during the last three decades. In 2000 , geothermal resources have been identified in over 80 countries and there are quantified records of geothermal utilization in 58 countries in the world [11]. As of 2004, there are over a million units installed worldwide providing $12 \mathrm{GW}$ of thermal capacity. Each year, about 80,000 units are installed in the USA and 27,000 in Sweden.

The typical ground source heat pump loop configuration was discussed by Gerald W. Hutter [12]. He introduced the benefits of GSHP use and the keys to successful GSHP market penetration. Geothermal heat pump systems can be installed in closed and open loop configurations that include vertical, horizontal, and surface water closed loops and standing column/water well open loops. There are three keys to successful market penetration of GSHP that has occurred since the 1980s: education and the increase of technology awareness, first cost reduction and provision of financial assistance to end users. The combination of a simple, efficient technology coupled with a growing awareness of benefits, a rapidly developing infrastructure and attractive paybacks has resulted in successful proliferation of geothermal heat pumps.

In 2010 Louis Lamarche et.al, [13] reviewed and introduced some methods to improve the design of ground-source heat pump systems. The found that, the heat transfer from the fluid to the ground is influenced by the thermal borehole resistance between the fluid and the borehole surface and also by the interference resistance between the 2 or 4 pipes inside the borehole.

\section{Geothermal Potential In Jordan}

The geothermal investigations found out a rich geothermal potential in low temperature resources spread amongst several geothermal fields. The distribution of the geothermal 
resources in Jordan is shown in Fig. 1. The general characteristics of the main geothermal fields in Jordan [14] are summarized in Table I.

TABLE I: GENERAL CHARACTERISTICS OF THE MAJOR GEOTHERMAL FIELDS IN JORDAN [8]

\begin{tabular}{lll}
\hline \hline Geothermal field & Flow Rate $(\mathrm{m} 3 / \mathrm{hr})$ & Temp. $\left({ }^{\circ} \mathrm{C}\right)$ \\
\hline Himmeh springs & $300-3000$ & $38-44$ \\
Mukheibeh wells & $200-6000$ & $30-41$ \\
North Shuneh well & 700 & 57 \\
Queen Alia airport & $30-100$ & $30-45$ \\
Zara springs & $1-255$ & $34-55$ \\
Zarqa Ma'in springs & $1-350$ & $30-63$ \\
Wadi Ibn Hammad springs & $1-25$ & $35-41$ \\
TS-1D thermal well & 400 & 50 \\
Burbeitta spring & 315 & 39 \\
Afra springs & 376 & $45-47$ \\
Smeika thermal well & 50 & 57 \\
\hline \hline
\end{tabular}

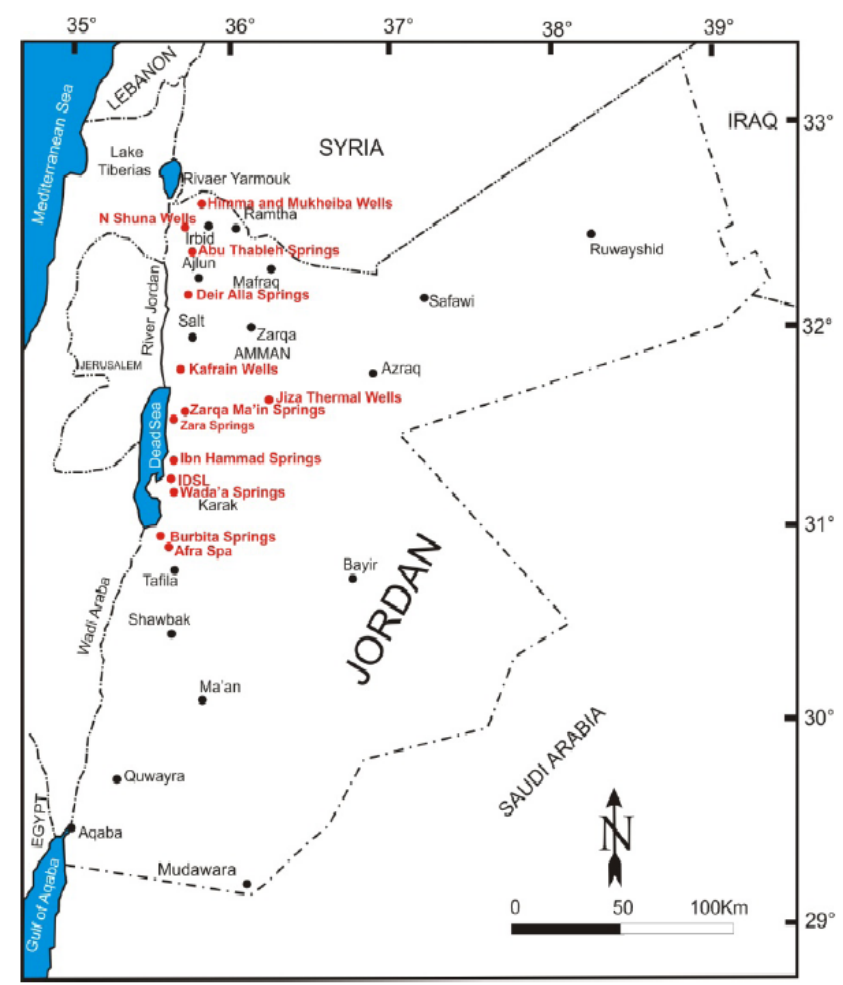

Fig. 1. Distribution of geothermal resources in Jordan

The location of nearly all the thermal springs and the hot boreholes are dictated by their proximity to the Dead Sea Rift. Thermal spring is distributed along the eastern escarpment of the Dead Sea Rift for distance about $200 \mathrm{~km}$, from Mukheibeh thermal field in the north to Afra and Burbeitta thermal field in the south. Most of the springs have temperature below $45^{\circ} \mathrm{C}$ except in two localities the temperature reaches up to $63^{\circ} \mathrm{C}$ (Zarqa Ma'in and Zara springs) [15].

\section{BUILdING AND Site SPECIFICATIONS}

The building plan is shown in Fig. 2. The building is located in Amman-Jordan. The maximum outside temperature is 32.9 in August. The minimum outside temperature is $4.2 \mathrm{C}$ in January. The inside design temperature is $24 \mathrm{C}$ with 55\% R.H for summer and 50\% R.H for winter. The total cooling load of the building is $13.4 \mathrm{~kW}$. The total heating load of the building is $17.7 \mathrm{~kW}$.

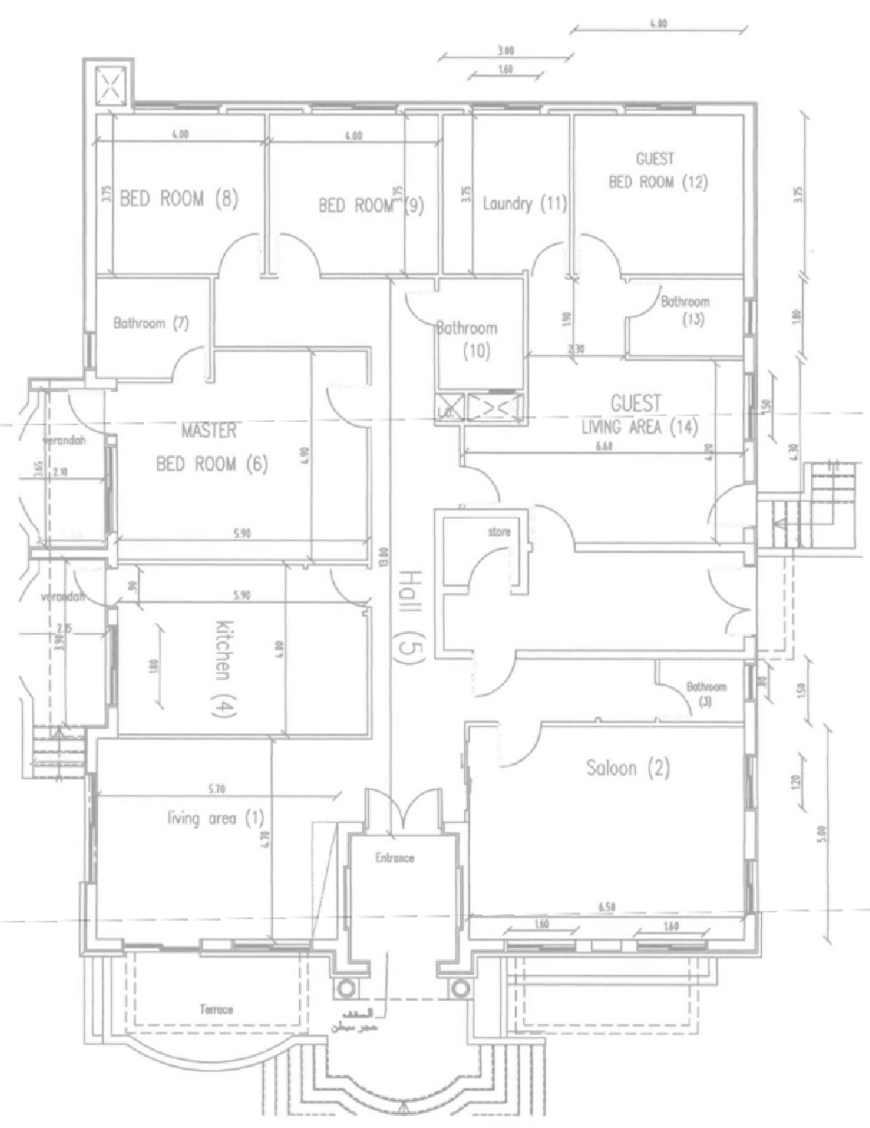

Fig. 2. Building Plan

\section{ENERGY SAVING IN DOMESTIC HOT WATER}

The energy saving by using geothermal heat exchanger is considered in this section. The calculations are based on implementing a geothermal system for a family of 6 persons. The hot water demand per person per day is $80 \mathrm{~L}$. The total hot water demand for 6 persons is 480 Liter per day.

Calculating the boiler load for domestic hot water

$$
Q_{h w}=\dot{m} C_{p}\left(T_{h w}-T_{c w}\right)
$$

where

$$
\begin{gathered}
\dot{m}=480 / 3600=0.1333 \mathrm{~kg} / \mathrm{sec} \\
C_{p}=4.186 \mathrm{~kJ} / \mathrm{kg} \cdot \mathrm{K} \\
T_{h w}=45 \mathrm{C} \\
T_{c w}=5 \mathrm{C} \\
Q_{h w}=0.1333 * 4.186 *(45-5)=22.32 \mathrm{~kW}
\end{gathered}
$$

Taking safety factor of $10 \%$ for domestic hot water load

$$
Q_{h w}=1.1 * 22.32=24.56 \mathrm{~kW}
$$

The boiler capacity is the sum of the total heating load and the domestic hot water load

$$
Q_{\text {Boiler }}=17.7+24.56=42.26 \mathrm{~kW}
$$

Installing a slinky loop geothermal will increase the water temperature entering the boiler 11 degrees. The temperature difference between the ground and the fluid in the loop 
provides the impetus for the energy movement. This will reduce the boiler load $6.144 \mathrm{~kW}$.

$$
Q_{h w}=0.1333 * 4.186 *(16-5)=6.144 \mathrm{~kW}
$$

This requires a 65.12 meter of polyethylene tube. Taking a loop diameter of 0.91 meter, results in 23 slinky loops. The geothermal heat exchanger installed in the ground increases the temperature of the water entering the boiler from 5 to 16 C. This system reduces the fuel consumption as follows.

The total boiler load without installing the geothermal system is $42.26 \mathrm{~kW}=152136 \mathrm{~kJ} / \mathrm{hr}$

The amount of fuel needed for the heating season;

$$
M_{f}=\frac{24 \dot{Q}_{\text {boiler }}(D D)}{T_{\text {in }}-T_{\text {out }} C V}\left(\frac{C_{d}}{e f f}\right)
$$

where

$$
\text { DD: degree days }=1067
$$

$C_{d}$ Empirical factor $=0.75$

$$
\begin{aligned}
& T_{\text {in }}=21 \mathrm{C} \\
& T_{\text {out }}=2 \mathrm{C}
\end{aligned}
$$

The required diesel fuel is $5481.4 \mathrm{~L} /$ season.

Installing the Geothermal system will reduce the fuel consumption to $4604.56 \mathrm{~L} /$ season

The amount of fuel saved after installing the geothermal system is $876 \mathrm{~L} /$ season

The amount of fuel saved after installing the geothermal system is $876 \mathrm{~L} /$ season

\section{ENERGY SAVING IN HVAC SYSTEMS}

Geothermal system can be used to reduce energy consumption in heating and cooling systems. For that a heat exchanger for heating or cooling air before entering the main coils of air handling unit. The first heat exchanger is placed in the AHU unit as extra room between the inlet of the outside air and the mixing box. The second heat exchanger which consists of pipe system with spiral shape placed in borehole underground at a depth between 5-8 $\mathrm{m}$. the material of the heat exchanger should have a high thermal conductivity such as galvanized steel. After placing the pipes underground it must be buried by high conductive grout to ensure a good contact between the heat exchanger pipes and the ground. The system should be supplied by a pump to circulate the water inside the pipes.

Using 3/4" galvanized steel for the heat exchanger a total length of $6.7 \mathrm{~m}$ is required. The installation of the geothermal heat exchanger leads to a $30 \%$ reduction during winter and $15 \%$ during summer. The reduction in cost can be referred to reducing the power consumption in the air handling unit coil. That means a lower capacity heating and coils are required. This reduces the number of rows for both heating and cooling coils. Consequently, the pressured drop in heating coils is reduced. Initial cost of the system is increased because geothermal heat exchanger is required. Besides that a circulating pump is needed. Drilling the borehole has the biggest share in initial cost increase.

\section{CONCLUSION}

Potential of energy saving using geothermal heat exchanger was studied in this paper. It was found that energy saving ranges between $15 \%$ and $30 \%$ by installing geothermal heat exchanger. The installation of geothermal systems in Jordan will have appositive influence on the economy because it will contribute in reducing the energy bill.

\section{REFERENCES}

[1] G. Axelsson and V. Stefansson, "Sustainable management of geothermal resources," Proceedings of International Geothermal Conference (IGC-2003), Reykjavik, Iceland, vol. 14-17, pp. 40-48, September, 2003.

[2] J. Lund and D. Freeston, "World-wide direct uses of geothermal energy 2000," Proceedings World Geothermal Congress 2000, Tohoku, Japan, pp. 1-21, May 28 - June 10, 2000.

[3] J. Lund, B. Sanner, L. Rybach, R. Curtis, and G. Hellström, "Geothermal (ground-source) heat pumps: a world review," Geo-Heat Center Bulletin, vol. 25, no. 3, pp.1-10, 2004.

[4] J. D. Deerman and S. P. Kavanaugh, "Simulation of vertical U-tube ground coupled heat pump systems using cylindrical heat source solution," ASHRAE Trans, vol. 97, pp. 287-95, 1991.

[5] Y. Gu and D. O'Neal, "Development of an equivalent diameter expression for vertical U-tubes used in ground-coupled heat pumps," ASHRAE Trans, vol. 104, pp. 347-55, 1998.

[6] C. Yavuzturk and J. D. Spitler, "Comparative study to investigate operating and control strategies for hybrid ground source heat pump systems using a short time step simulation model," ASHRAE Trans, vol. 106, no. 2, pp. 192-209, 2000.

[7] C. Yavuzturk, J. Spitler, and S. Rees, "A transient two-dimensional finite volume model for the simulation of vertical U-tube ground heat exchangers," ASHRAE Trans, vol. 105, no. 2, pp. 465-74, 1999.

[8] A. D. Chiasson, J. D. Spitler, S. J. Rees, and M. D. Smith, “A model for simulating the performance of a shallow pond as s supplemental heat rejecter with closed-loop ground-source heat pump systems," ASHRAE Trans, vol. 106, no. 2, pp. 107-21, 2000.

[9] M. Inalli and H. Esen, "Experimental thermal performance evaluation of a horizontal ground-source heat pump system," Appl Therm Eng, vol. 24, Iss. 14-15, pp. 2219-2232, October 2004.

[10] M. Inalli and H. Esen, "Seasonal cooling performance of a ground-coupled heat pump system in a hot and arid climate," Renew Energ, vol. 30, pp. 1411-1424, 2005.

[11] J. B. Fridleifsson, "Geothermal energy for the benefit of the people," Renewable and Sustainable Energy Reviews, vol.5, pp. 299-312, 2001.

[12] G. W. Huttrer, "Geothermal heat pumps: An increasingly successful technology," Renewable Energy, vol. 10, Iss. 2-3, pp. 481-488, February-March 1997.

[13] L. Lamarche, S. Kajl, and B. Beauchamp, "A review of methods to evaluate borehole thermal resistances in geothermal heat-pump systems," Geothermics, vol. 39, pp. $187-200,2010$.

[14] A. Swarieh, "Geothermal energy resources in Jordan, country update report," Proceedings of the World Geothermal Congress, Kyushu-Tohoku, Japan, 2000.

[15] A. Saudi and A. Swarieh, "Geothermal Energy Resources in Jordan, Country Update Report," Proceedings World Geothermal Congress, Antalya, Turkey, 24-29 April 2005.

Eng. Abeer Abu Raed is a lecturer of architectural Engineering at Al-Zaytoonah Private University of Jordan. She worked as Vocational and Technical Education Specialist (Arts \& Arch) at the the United Nations Relief and Works Agency (UNRWA). She finished her master from Anhalt University of Applied Sciences University, Dessau Germany in 2005. She has several publications in renewable energy and served as a member of the organizing committees for several international conferences and workshop.

Dr. Ahmad Sakhrieh is an assistant professor of Mechanical Engineering at the University of Jordan. He finished his PhD from Lehrstuhl Für Technische Thermodynamik Friedrich-Alexander University, Erlangen-Nürnberg, Germany in 2006. He has more than 25 publications in thermodynamics and renewable energy applications and served as a member of the organizing committees for several international conferences. 